Agro-Science Journal of Tropical Agriculture, Food, Environment and Extension Volume 13 Number 2 May 2014 pp. 24 - 36

ISSN III9-7455

\title{
DETERMINANTS OF AGRO-INPUTS REDEMPTION UNDER THE ELECTRONIC WALLET INITIATIVE IN NIGERIA
}

\author{
Coker A. A. \\ ${ }^{1}$ Department of Agricultural Economics and Extension Technology, School of Agriculture and \\ Agricultural Technology, Federal University of Technology, Minna, P.M.B. 65, Minna, Nigeria. \\ E-mail-ayodejicoker@futminna.edu.ng
}

\begin{abstract}
The study assessed the spread of farmers and participation in terms of input redemption and the determinants of farmers redeemed with agro-inputs under the electronic-wallet initiative of the Growth Enhancement Support Scheme of the On-going Agricultural Transformation Agenda. Secondary data covering the Nigerian nation, with states and zonal breakdowns were used for the study. Analytical tools included the use of descriptive analysis such as mean, percentages coefficient of variation and graphical analysis. Other non-parametric and parametric tools employed included the analysis of variance and multiple regression analysis. The study revealed that the northern parts of the country accounted for about $90 \%$ of the total number of farmers redeemed with agro-inputs under the scheme, with the north-west accounting for about $50 \%$ of this figure. The performance of local government participation was generally above par given the average performance of $81.47 \%$ across zones, with over $90 \%$ active LGA participation recorded in the south-south and south-west. The analysis of variance test showed that the zonal achievements in terms of agro-inputs redeemed were significantly different across the 6 zones within the country. Ironically, the coefficient of variation index revealed a higher stability in farmers redeemed in the south west zone with an index of 1.15, in-spite of the placement of the zone relative to the northern zones. Farmers turn-out and number of active local government areas were also observed to be significant determinants of farmers redeemed with agro-inputs at $1 \%$ and $10 \%$ respectively. The study recommended the need for enhanced political support for the scheme at the state and local government levels, effective farmer education and mobilization, enhanced supervision of agro-input dealers and redemption centers, effective alignment of all on-going food security projects with the scheme, while prioritizing the scheme for targeted budgetary allocation.
\end{abstract}

Keywords: Agro-input redemption, Electronic-wallet, Growth Enhancement Support Scheme, Agricultural Transformation Agenda

\section{INTRODUCTION}

Nigeria is one of the lower medium economies in the world with a GDP of $\$ 510$ billion dollars, following rebasing in 2014 and was among the few countries that witnessed growth in spite of the global economic downturn with a figure estimated at $7.3 \%$ in 2011 (Doreo Institute, 2013). The country's potential lies in its rich natural and human resources, with a population of 163 million people (NBS, 2012); there is also huge domestic market that attracts investors globally. Nigeria's agro ecology also sustains the cultivation of a wide variety of crops, including staples like rice, millet, sorghum, maize, cassava, yam, and cowpeas and cash crops like cocoa, groundnuts, rubber, and oil palm. Farming and livestock rearing are the main sources of livelihood for more than 70 percent of households (Banful et al., 2010). Following the GDP rebasing, agriculture which used to be a huge contributor to the economy lost its place following the rise in the impact of the service sector which now contributes $52 \%$ of the GDP compared to the $23 \%$ from agriculture. Worse still, Nigeria's promising agricultural potential has yet to be realized. Between 1960 and 2005, Nigeria's cereal yield per hectare grew by only about 40 percent. This contrast to the 150 percent increase in India, and a 200 percent increase in Pakistan, countries that had similar levels of productivity at the beginning of that period (Nationmaster.com 2010). Ayinde et al, (2009) revealed that fertilizer usage, the quantity of fertilizer distributed, the price of fertilizer and the policy period as policy variables were found to have significant effect on to crop production. It was further argued that productivity increases in the country will be premised on science-based technology; the use of fertilizer, improved seed and crop protection products. To 
enhance productivity in Nigeria, Ayoola (2001) affirmed numerous input subsidies have been implemented to enhance adoption of improved technologies (agro-inputs) and redistribute incomes to favour the poor resource famers. According to the researcher, agricultural subsidy policy had witnessed many changes dating back to the late 60s and early 70s. The policy direction became centralized and its scope widened to cover food crops. According to FGN (2010), 75\% fertilizer policy was implemented by the FGN between 1976 and 1979, while states subsidies ranged from $0-50 \%$. Following these, various levels of subsidies have been implemented on improved seeds; agrochemicals and tractor hire which ranged from 25 percent to 50 percent. However, he noted that the implementation of these policies has not been effective, largely fraught with colossal leakages, corruption, with the subsidy not getting to the intended farmers. Other issues included the emergence of dependency syndrome among farmers, absence of poor allocative role of price following distortion created by subsidy, low morale among private sector participation to build up enterprise initiative, among others (Ayoola, 2001). Nagy and Edun (2012) noted that both state and federal governments have subsidized fertilizer, sometimes at rates as high as 95 percent. It was further argued that even though the subsidy programs absorbed large proportions of the national budget, the impact of the programs on agricultural productivity has been mixed at best given that the subsidy programs have been plagued by pervasive problems of late delivery of fertilizer, and delivery of inappropriate quantities and types of fertilizer. Rent-seeking activities and political manipulation have also resulted in diversion of subsidized fertilizer from the intended beneficiaries. Eboh et al, (2006) hinted that the history of fertilizer subsidy policy in Nigeria falls under seven distinguishable regime periods alternating between era of fertilizer regulation and non-regulation. According to them, levels of subsidy ranged between $25 \%$ and $85 \%$ at the federal and state levels, while it was noted that the reduction of import tariff on fertilizers from $10 \%$ in 1996 to $5 \%$ in 1997 and $0 \%$ in 2000 contributed to reduction in the rate of decline in fertilizer consumption. They however noted that fertilizer use declined from about 461,000 $\mathrm{mt}$ in 199394 to mere $173,000 \mathrm{mt}$ in $1999-2000$, a decline of about 63\%. The FMARD (2010) noted that between 1977 and 1996, the country implemented an annual programme of monopolized fertilizer procurement and distribution that was plagued by colossal wastages and diversions and that in 1997, the agriculture sector was abruptly liberalized but without the support of the private sector, which initially was unable or unwilling to respond. According to the source, fertilizer use fell from a peak of 1.2 million tons in 1992 to 56,708 tons in 1997. This prompted a reintroduction of federal fertilizer subsidy in 1999 at a level of $25 \%$ which was implemented until 2011. In addition to this, states further subsidized fertilizer as they deemed necessary. However, evidence abound that a large majority of the subsidized product does not reach those it is intended for, or if it does it is either delayed to a point of being of little use, or it is available for sale to the target group at near commercial rates.

Against the aforementioned background, the FGN in 2008 made its intention known to withdraw completely from direct involvement in input procurement, particularly fertilizers when a veritable alternative is identified. Thus, following the successful use of vouchers as a means of targeting subsidies to identified groups in Kyrgyzstan, Malawi, Albania, Rwanda and Nigeria, International Fertilizer Development Corporation (IFDC) and the National Programme for Food Security (NPFS) started with pilot fertilizer voucher program in Kano, Bauchi and FCT in 2008 (NPFS, 2010). The basis for the Voucher Scheme is the consideration that the current fertilizer subsidies paid by the FGN and the States can be more efficiently delivered to targeted beneficiaries utilizing a voucher system, by encouraging the delivery of such through the development of a private sector distribution channel and facilitating the development of commercial credit products to aid in this development (NPFS, 2010). Abstracting from the success of the voucher scheme in pilot states in such areas like reach, cost effectiveness and private sector participation and given the need to further stimulate a thriving private sector fertilizer industry, the FGN in 2011, following the initiation of the Agricultural Transformation Agenda (ATA), introduced the Growth Enhancement Support Scheme (GESS) with a view to ensuring that government abdicate agro-input procurement and distribution, particularly fertilizers while supporting farmers through smart subsidies. The GESS is expected to move farmers from subsistence to commercialized farming through fiscal savings, greater returns on investment, targeting highest poverty level and providing exit strategy. The programme targets 20 million farmers by 2015 in phased manner and is expected to result in a total programme benefit of US $\$ 40$ billion, a 16 fold benefit versus cost, aside the financial benefit of US\$500 per farmer (FMARD, 2011). The initiative is also expected to leverage on the use of mobile technology to achieve scale (electronic wallet). The implementation of the programme is ongoing with over 10 million farmers reached (over 50\% achievement). According to Cellulant, the GESS in dollar terms effected $\$ 294 \mathrm{~m}$ value of subsidies disbursement on behalf of the Federal and State Governments into the wallets of farmers. The organization noted that while farmers used $\$ 52$ million 
of the subsidy deposits, agro-dealers received $\$ 50$ million as matching funds from farmers, thereby accruing a saving of about \$192 million (\$29.7 billion). In their work on the growth enhancement support and food security, Tiri et al., (2014) revealed that the scheme has been an innovative approach to fertilizer subsidy and other input administration through electronic system that ensures that only registered farmers benefit through engagement of the private sector in the delivery and distribution of fertilizer and other input directly to the farmers. The researchers noted that the key issues in the scheme's success are institutional support, legislative backing and increase share of government budget to agriculture. According to them, the scheme will play a primary role in increasing farm productivity and incomes of rural farmers. Furthermore, FMARD (2014) affirmed that the GESS ended the 4 decades of corruption in the seed and fertilizer sector within 90 days. According to the Ministry, the scheme ended direct procurement and distribution of seeds and fertilizer by government; introduced cell phone based system to send subsidies via electronic vouchers and developed the first ever data base of farmers. Ojumu and Adeyelu (2014) further noted that the GESS is a self sufficiency strategy in rice production through the provision of agro-input such as fertilizers and other agro-chemicals to farmers.

In-spite of this development, there has been complaints on the inadequate access, inability to redeem and use agro-inputs in-spite of the coming of the e-wallet initiative of the GESS. An international organization argued that the GESS is more of hype while doubting the effectiveness of the initiative. Personal interaction with a farmer in the south western part of the country revealed that even though the input alert (e-message) through the mobile phone was received, his redemption center was at Ogun State whereas he resides in Lagos. Interaction with rice farmers under the programme in Kano also revealed that the programme was actually fraught with delays in first year of implementation, but picked up subsequently, with over $60 \%$ of farmers benefitting. Further interaction with rice farmers in three communities each in Badeggi, Bida and Wushishi Local Government Councils revealed that farmers were still not accessing the platform the way they would have wanted. It is thus against this background that this study reviews the spread and participation of farmers in the GESS and ascertained the determinants of farmers redeemed with agro-inputs under the scheme. The specific objectives of the study were to: (i) describe the spread of beneficiaries in terms of participation and input redemption under the GESS across states and zones in Nigeria; (ii) ascertain the determinants of farmers redeemed with agro-inputs under the scheme; and (iii) discuss the challenges under the scheme and their implications for effective implementation of the on-going Agricultural Transformation Agenda. The justification of the study stems from the fact that policy makers will be interested in ascertaining the effectiveness of the scheme with the view for sustainability or fine-tuning the entire strategy. The private sector, especially the farmers and the agro-input dealers will also be desirous that the scheme progresses effectively with the view for sustainability, commercialization and improved well-being.

\section{MATERIALS AND METHODS Area of Study}

Nigeria is derived from the word 'Niger' which is the name of the river that constitutes the most remarkable geographical feature of the country. The country attained independence from Britain on October 01, 1960, and became a Republic in 1963.The Country is located in West Africa and is bordered by Cameroon to the south east, Benin to the south west, and Niger to the north. Nigeria has a land area of $924,000 \mathrm{~km}^{2}$ and a population of 140,003,542 million (National Population Commission, 2007). The climate is semiarid in the north and becomes increasingly humid in the south, with mean annual temperature ranging from $31^{0}$ $28^{\circ} \mathrm{c}$ in the south. Rainfall is the most important climatic factor influencing agriculture and three broad ecological zones are commonly distinguished: the Northern Sudan savannah $(500-1000 \mathrm{~mm})$, the guinea savannah zone or middle belt $(1000-1,500 \mathrm{~mm})$ and the southern rainforest zone (1,500-4,000mm). Generally, rainfall patterns are marked by an alternation of wet and dry seasons of varying duration. In the north, rainfall lasts from May to September with a peak in August, while in the south, rainfall is bimodal, increasing steadily from January and reaching its peak in September. About two thirds of the area cropped is located in the north with the rest equally divided between the middle and southern zones (ADB, 2006).

Over 60 per cent of the country's population lives in rural areas. The average population density of $118 \mathrm{~km}^{2}$ masks the considerable differences that exist between the densely populated south west of Nigeria, where much of the urban population live, and the less concentrated north. The economy is characterized by a large rural, mostly agricultural based traditional sector and a smaller, largely urban, more capital intensive sector. The average per capital income (estimated by the World Bank in 2006) was US $\$ 300$ per annum. Although the country relies heavily on the petroleum sector which generates over half of government revenue and more than 90 per cent of foreign exchange earnings, agriculture continues to play a focal role in the economy. The sector currently contributes about 32 per cent to the GDP, with rain fed crop production 
accounting for about 89.06 per cent of this total and livestock, forestry and fisheries for 6.38 per cent, 1.25 per cent and 3.31 per cent respectively. The sector makes a contribution to exports (mostly cocoa, rubber, leader and hides) but, prior to the oil boom (19721980s), Nigeria was a major exporter of a range of agricultural commodities. Nigeria now has to import large quantities of food with wheat and rice being the major crops imported. Mixed small scale farming is the predominant form of production and between 90 to 95 per cent of the total output is accounted for by households that cultivate about 2 ha $(0.5$ ha in the south and over 4ha in the north) of land. Deficiency of annual rainfall is the main constraint to agriculture in the north but, more importantly, the distribution in space and time and dependability of the rainfall is a constraint over most of the country (ADB, 2006). Coker $\boldsymbol{e t}$ al., established that output of major crops in the country has been on the rise between 2001 and 2011 from 103.6 million $\mathrm{M} /$ tons to 167.8 million $\mathrm{M} /$ tons in 2011 . The mean output growth rate stood at $5.5 \%$, fluctuating from $3.8 \%$ in 2002 to a peak of $8.5 \%$ in 2004 and then witnessed a decrease to $5.8 \%$ in 2010 . However, output increases was observed to have been largely due to acreage expansion given that productivity per hectare has been low.

From Lagos as the economic capital, the nation now has Abuja as the Federal Capital and is currently made up of 36 States, 774 Local Government Councils, 6 Geo-political Zones and 3 major ethnic groups; Hausa, Yoruba and Igbo, reflecting also the major Nigerian languages. However, there are about 250 tribes in the country with their distinct dalects (languages).

\section{Scope of Study and Sources of Data}

The study covers the 36 States in Nigeria, including the Federal Capital Territory. The zonal categorization of the country was taken into cognizance for ease of data management and analysis. Data used were mainly secondary, complemented with primary information obtained from farmers in the course of regular survey mandate. Data sources for the accomplishment of the objectives of the study and specifically, for the estimation of the parameters of the models were from the Federal Ministry of Agriculture and Rural Development (FMARD), National Bureau of Statistics (NBS) and the National Programme for Food Security (NPFS).

\section{Analytical Technique}

This study made use of in-depth descriptive analysis of the spread of registered farmers, farmers turn-out and those redeemed with agro-inputs with focus on fertilizer. Descriptive analysis was undertaken to effectively conduct a cross-examination of the Federal Government growth enhancement support scheme with a view to ascertaining extent of performance, buy in across state and zones with the view to identifying issues and coming out with recommendations. Percentages, ratios, tabular presentation, analysis of variance, co-efficient of variation and graphical analysis were also used to explicitly bring out the trend and depth of farmers participation in the GESS across the 36 states of the Federation, including the FCT. These tools were used to achieve objectives one and three of this study, while objective two was accomplished by the use of multiple regression analysis.

\section{Model Specification}

The specification of economic-models is always based on economic theories and on available information related to the phenomenon being studied (Koutsoyiannis, 1979). For the purpose of this study therefore, the multiple regression model was utilized.

\section{Multiple Regression Analysis}

This was used to determine the influence of the independent variables on the number of farmers redeemed with agro-inputs. This was used to analyze objective II of this study

Hence, the model was specified as:

$\mathrm{Y}=\left(\begin{array}{llllll}\mathrm{X}_{1}, & \mathrm{X}_{2}, & \mathrm{X}_{3}, & \mathrm{X}_{4}, & \mathrm{X}_{5} & \mathrm{X}_{6}\end{array}\right.$

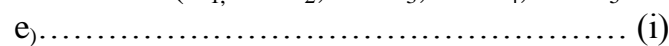

$\mathrm{Y}=$ Total number of farmers redeemed with agroinputs (

$\mathrm{X}_{1}=$ Registered farmers (No.)

$\mathrm{X}_{2}=$ Farmers turnout (No.)

$\mathrm{X}_{3}=$ No of active agro-input redemption centers (No.)

$\mathrm{X}_{4}=$ Total no of agro-input redemption center (No.)

$\mathrm{X}_{5}=$ No of active Local Government Areas (No.)

$\mathrm{X}_{6}=$ Total no of Local Government areas (No.)

$\mathrm{e}=$ Error term

The explicit forms of the model are specified as follows:

\section{i. Linear Functional Form:}

$\mathrm{Y}=\mathrm{bo}+\mathrm{b}_{1} \mathrm{X}_{1}+\mathrm{b}_{2} \mathrm{X}_{2}+\mathrm{b}_{3} \mathrm{X}_{3}+\mathrm{b}_{4} \mathrm{X}_{4}+\mathrm{b}_{5} \mathrm{X}_{5}+\mathrm{b}_{6} \mathrm{X}_{6}+\mathrm{e} \ldots \ldots$. (ii)

ii. Double Log (Cob Douglas) Functional Form:

$\mathrm{LnY}=\mathrm{bo}+\mathrm{b}_{1} \operatorname{LnX}_{1}+\mathrm{b}_{2} \mathrm{LnX}_{2}+\mathrm{b}_{3} \operatorname{LnX} \mathrm{X}_{3}+\mathrm{b}_{4} \operatorname{LnX}_{4}+\mathrm{b}_{5} \operatorname{Ln} \mathrm{X}_{5}+\mathrm{b}_{6} \operatorname{LnX}_{6} \mathrm{e} \ldots$ (iii) iii. Semi-log Functional Form

$\mathrm{Y}=\mathrm{bo}+\mathrm{b}_{1} \operatorname{LnX}_{1}+\mathrm{b}_{2} \operatorname{LnX} \mathrm{X}_{2}+\mathrm{b}_{3} \operatorname{LnX} \mathrm{X}_{3}+\mathrm{b}_{4} \operatorname{LnX}_{4}+\mathrm{b}_{5} \operatorname{LnX}_{5}+\mathrm{b}_{6} \operatorname{LnX}_{6}+\mathrm{e} \ldots$ (iv)

\section{iv. Exponential:}

Lny $=$ bo $+b_{1} X_{1}+b_{2} X_{2}+b_{3} X_{3}+b_{4} X_{4}+b_{5} X_{5}+b_{6} X_{6}+e \ldots \ldots$ (v)

Where bo- $b_{10}=$ Regression coefficients.

$\mathrm{e}=$ Error term. 
Analysis of Variance (ANOVA) was the test statistic employed and it is specified as the ratio of the between and within variation in the zonal data employed for this study. It follows an F distribution. Total Sum of Squares - the total variation in the zones. It is the sum of the between and within variation.

\section{Hypothesis testing:}

The null and alternative hypotheses tested were that: Ho: $\mu_{1}=\mu_{2}=\mu_{3}=\mu_{4}=\mu_{5}=\mu_{5}$ - The mean number of farmers redeemed with agro-inputs is statistically equal across the six zones.

Ha: At least farmers redeemed with agro-input in one zone are not statistically equal with those of the other zones.

\section{RESULTS AND DISCUSSIONS \\ Beneficiaries Involvement across States and Zones under the GESS}

A cursory review of available data revealed that 3,907,445 farmers were registered for the 2012 wet season under the GESS out of which 1,677,248 (42.92\%) turned out and 1,128,673 (28.89\%) were redeemed. A cursory review of the registered farmers established that Bauchi State had the largest numbers of farmers with 321,605 (8.23\%) while Lagos accounted for the least with $20,317(0.52 \%)$. Ironically however, Kano State witnessed the highest turnout of farmers with 279, 787 while Rivers State came rear with 2,048 farmers. With regards to the number of farmers redeemed with agro-inputs, Kano State topped the list with 189,300 farmers (16.77\%). This came as a surprise, given that the fact that Bauchi State witnessed the highest number of registered farmers even though Kano State recorded the highest farmer turn-out. Rivers State witnessed the least number of farmers redeemed with 1,177 farmers; this did not come as a surprise given that the State witnessed the least number of farmer turn-out.

The zonal analysis revealed that the North West and North East Zones witnessed the highest numbers of farmer registration during the 2012 wet season, accounting for $24.82 \%$ and $24.05 \%$ of the $3,907,445$ farmers registered respectively (Table 1). However, the North West had the highest numbers of farmer turn-out accounting for $49.04 \%$ of the total while the South East and South west Zones accounted for $3.17 \%$ and $3.11 \%$ respectively. This development is not unconnected to the low number of farming families in these zones, their size and peculiar terrain. The review established the North West accounted for $49.70 \%$ of the total farmer redeemed with agro-inputs (Figure 2) followed by the North East at $20.8 \%$ while South East and South West took the rear at $2.7 \%$ and $2.75 \%$ of the total respectively. With respect to the agro-input redemption centers, the North East had more active centers relative to the total targeted (9\%), followed by the South West at $77.11 \%$ while the North West was active in $38.85 \%$ of the 157 redemption centers earmarked. This is worrisome given the top placement of the zone with respect to the number of farmers registered. The performance of Local Government participation was generally above par given the average performance of $81.47 \%$ across zones, with over $90 \%$ active LGA participation recorded in the South-South and South West. This becomes ironical when placed against the $13.25 \%$ and $9.35 \%$ farmer redemption relative to the population of farmers registered.The result of the Analysis of Variance (Table 2.0) showed that the F-Value of 5.43 was significant at 1 percent and was greater than the critical $F$ Value of 2.53 , implying that the null hypothesis is rejected and the alternative hypothesis accepted meaning that the zonal achievements are statistically significant from each other. It thus implies that the differences between the zones are not due to random error but as a result of the zonal effect which had caused the mean in one zone to be different from the other others. The Coefficient of Variation (CoV) across the zones revealed a higher coefficient of 1.15 for the South-South Zone, implying that there was higher stability in farmer redeemed with inputs in the Zone, followed by the North West and North East Zones which returned coefficient of 0.79 each. The South East Zone was the least stable in terms of farmers redeemed with agro-inputs with a coefficient of 0.2 . 


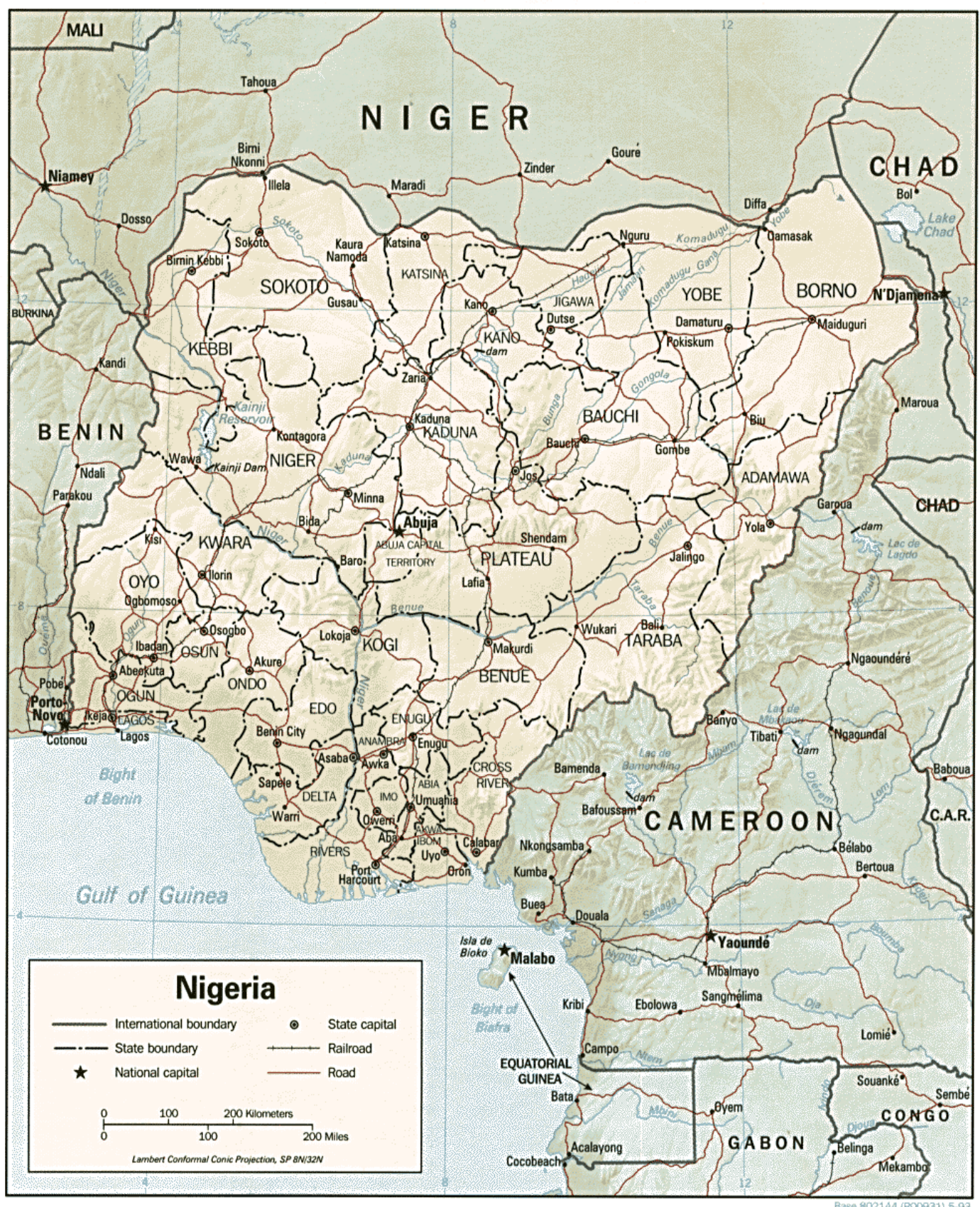

Figure 1: Map of the Federal Republic of Nigeria Source: Internet window 
Coker A. A.

Table 1.: Zonal Performance under the GESS

\begin{tabular}{|c|c|c|c|c|c|c|c|c|c|c|c|c|}
\hline Zones & $\begin{array}{c}\text { Farmers } \\
\text { Redeemed }\end{array}$ & $\%$ & $\begin{array}{c}\text { Farmers } \\
\text { Regt. }\end{array}$ & $\%$ & $\begin{array}{l}\text { Farmers } \\
\text { Turnout }\end{array}$ & $\%$ & $\begin{array}{c}\text { Total } \\
\text { Redemption } \\
\text { Centers }\end{array}$ & $\begin{array}{c}\text { Active } \\
\text { Redemptio } \\
\text { n Centers }\end{array}$ & $\begin{array}{c}\% \text { of } \\
\text { Active } \\
\text { over } \\
\text { Total } \\
\text { Centre }\end{array}$ & $\begin{array}{l}\text { No of } \\
\text { LGCs }\end{array}$ & $\begin{array}{l}\text { Active } \\
\text { LGAs }\end{array}$ & $\begin{array}{c}\text { \% of } \\
\text { Active } \\
\text { over } \\
\text { Total } \\
\text { LGAs }\end{array}$ \\
\hline $\mathrm{NC}$ & 208,362 & 18.46 & 774,366 & 19.82 & 320,830 & 19.13 & 159 & 104 & 65.41 & 131 & 88 & 67.18 \\
\hline $\mathrm{NE}$ & 234,821 & 20.81 & 939,613 & 24.05 & 322,879 & 19.25 & 125 & 107 & 85.60 & 91 & 75 & 82.42 \\
\hline NW & 560,932 & 49.70 & 969,774 & 24.82 & 822,577 & 49.04 & 157 & 61 & 38.85 & 195 & 150 & 76.92 \\
\hline SE & 31,175 & 2.76 & 420,867 & 10.77 & 53,146 & 3.17 & 84 & 56 & 66.67 & 95 & 72 & 75.79 \\
\hline SS & 62,313 & 5.52 & 470,411 & 12.04 & 105,701 & 6.30 & 113 & 61 & 53.98 & 127 & 123 & 96.85 \\
\hline \multirow[t]{2}{*}{ SW } & 31,070 & 2.75 & 332,414 & 8.51 & 52,115 & 3.11 & 166 & 128 & 77.11 & 138 & 125 & 90.58 \\
\hline & $1,128,673$ & & $3,907,445$ & & $1,677,248$ & & 804 & 517 & 64.30 & 777 & 633 & 81.47 \\
\hline
\end{tabular}

Source: FMARD 2013 Revised Score Card Team Report.

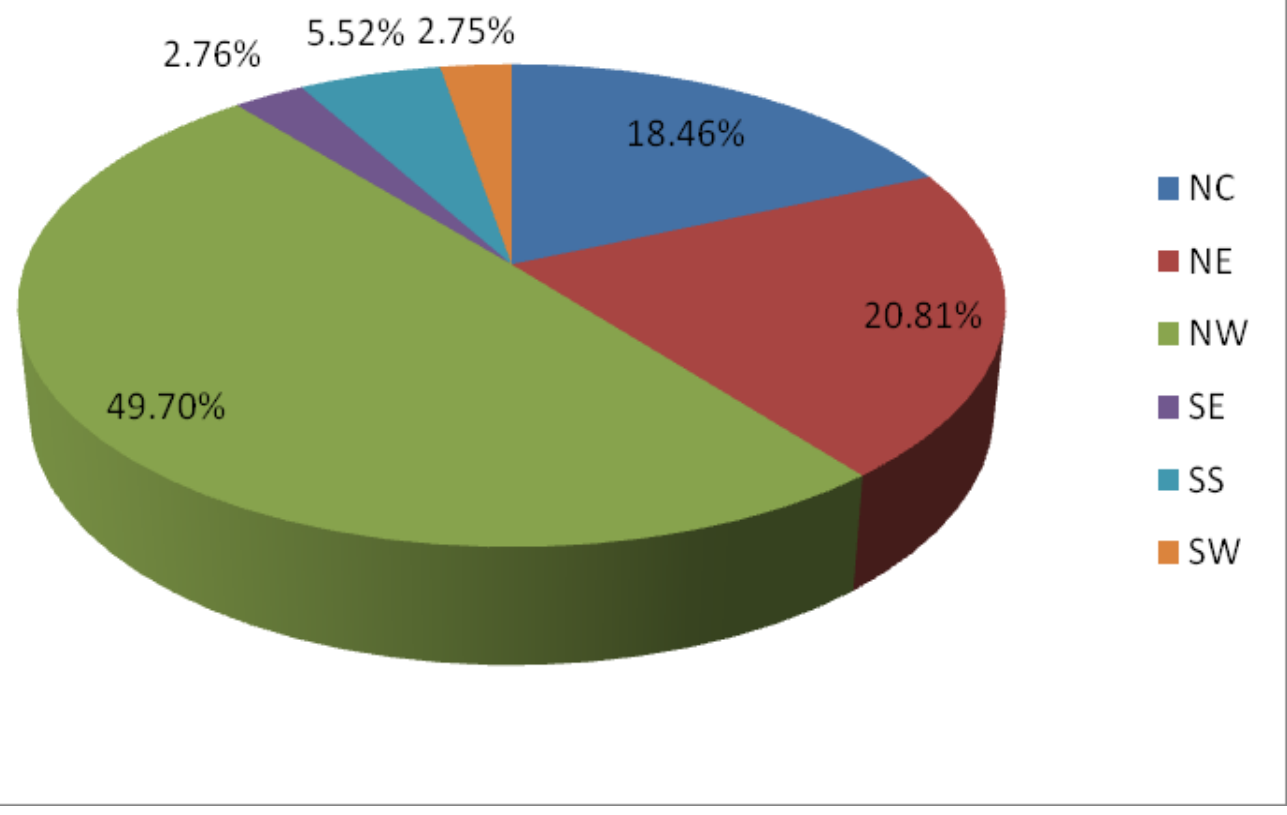

Figure 2: Farmers redeemed with agro-inputs

Table 2: Summary of ANOVA Result

\begin{tabular}{|c|c|c|c|c|c|c|}
\hline Groups & Count & Sum & Average & Variance & Std Dev & $\mathrm{COV}$ \\
\hline Zone 1 & 7 & 208362 & 29766 & 82027204 & 9056,887103 & 0.30 \\
\hline Zone 2 & 5 & 234821 & 46964.2 & $1,39 \mathrm{E}+09$ & 37324,19194 & 0.79 \\
\hline Zone 3 & 7 & 560932 & 80133.14 & $3,98 \mathrm{E}+09$ & 63078,83985 & 0.79 \\
\hline Zone 4 & 5 & 31175 & 6235 & 964224,5 & 981,9493368 & 0.16 \\
\hline Zone 5 & 6 & 62313 & 10385.5 & $1,43 E+08$ & 11965,6107 & 1.15 \\
\hline Zone 6 & 6 & 31070 & 5178.33 & 11382234 & 3373,756699 & 0.65 \\
\hline \multicolumn{7}{|l|}{ ANOVA } \\
\hline Source of Variation & $S S$ & $D f$ & $M S$ & $F$ & $P$-value & F crit \\
\hline Between Groups & $2,78 \mathrm{E}+10$ & 5 & 5559151829 & 5.429773 & 0.00113092 & 2.533555 \\
\hline Within Groups & $3,07 \mathrm{E}+10$ & 30 & 1023827731 & & & \\
\hline Total & $5,85 \mathrm{E}+10$ & 35 & & & & \\
\hline
\end{tabular}


Agro-input Redemption Performance across States and recorded the highest quantities of redeemed maize seeds Zones

$(983.33 \mathrm{mt})$ and rice seeds $(3482.74 \mathrm{mt})$ representing Analysis of agro-inputs redeemed by farmers showed that a $19.49 \%$ and $51.35 \%$ respectively. review of the zonal total of 133,248.10 mt of assorted fertilizers, 5,044.73mt of agro-inputs redeemed revealed that the North West Zone maize and $6,781.65 \mathrm{mt}$ of rice seeds were redeemed by recorded the highest quantities of fertilizers redeemed 1,128,673 farmers during the 2012 wet season (Table 3). accounting for $62.53 \%$ of the total fertilizer redeemed Assuming that all redeemed farmers benefitted from followed by the North Central at $15.14 \%$ while the South fertilizers, available data revealed that fertilizer redeemed East came rear accounting for 2.35\% of the total (Figure 2). ranged from about 2 bags-3 bags of fertilizer per capita Similar trend was observed for maize and rice redeemed across the zones. This aligns with the 3 bags targeted per where the North Central accounted for $52.28 \%$ and $75.31 \%$ farmer under the GESS initiative. The average input of the total redeemed with 2,637.21 mt and 5,107.54mt of redeemed per state stood at 3,701.34 mt, 144,135 mt and maize and rice seeds respectively (Figures 3 and4).

$188.38 \mathrm{mt}$ for fertilizers, maize and rice seeds respectively.

Katsina State witnessed the highest quantities of redeemed

fertilizers put at $49,811 \mathrm{mt}(37.38 \%)$ while Kano State

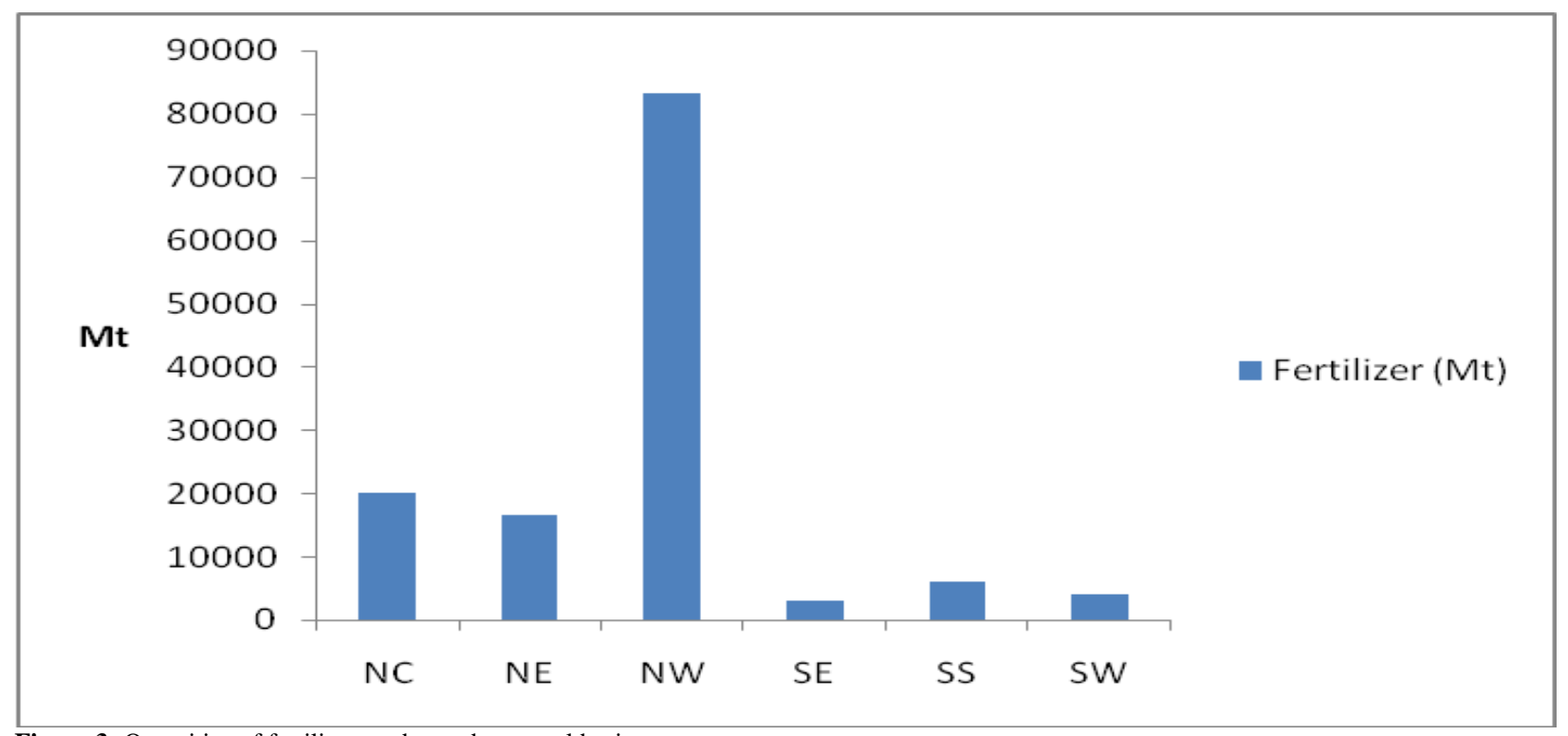

Figure 3: Quantities of fertilizers redeemed on zonal basis

Table 3: Agro-inputs Redeemed by Farmers

\begin{tabular}{ccccc}
\hline Indicator & Unit & Fertilizer & Maize & Rice \\
\hline Total Agro-inputs Redeemed & Mt & $133,248.1$ & $5,044.73$ & $6,781.65$ \\
Mean Quantities of Agro- & Mt & $3,701.34$ & 144.14 & 188.38 \\
inputs Redeemed per State & Mt & $49,811^{*}$ & $983.33^{* *}$ & $3,482.74 * *$ \\
Max Input Redeemed & $\%$ & 37.38 & 19.49 & 51.35 \\
Max Input as \% of Total & $\%$ & & \\
\hline
\end{tabular}

\footnotetext{
* Recorded at Katsina State; ** Recorded at Kano State
} 
Coker A. A.

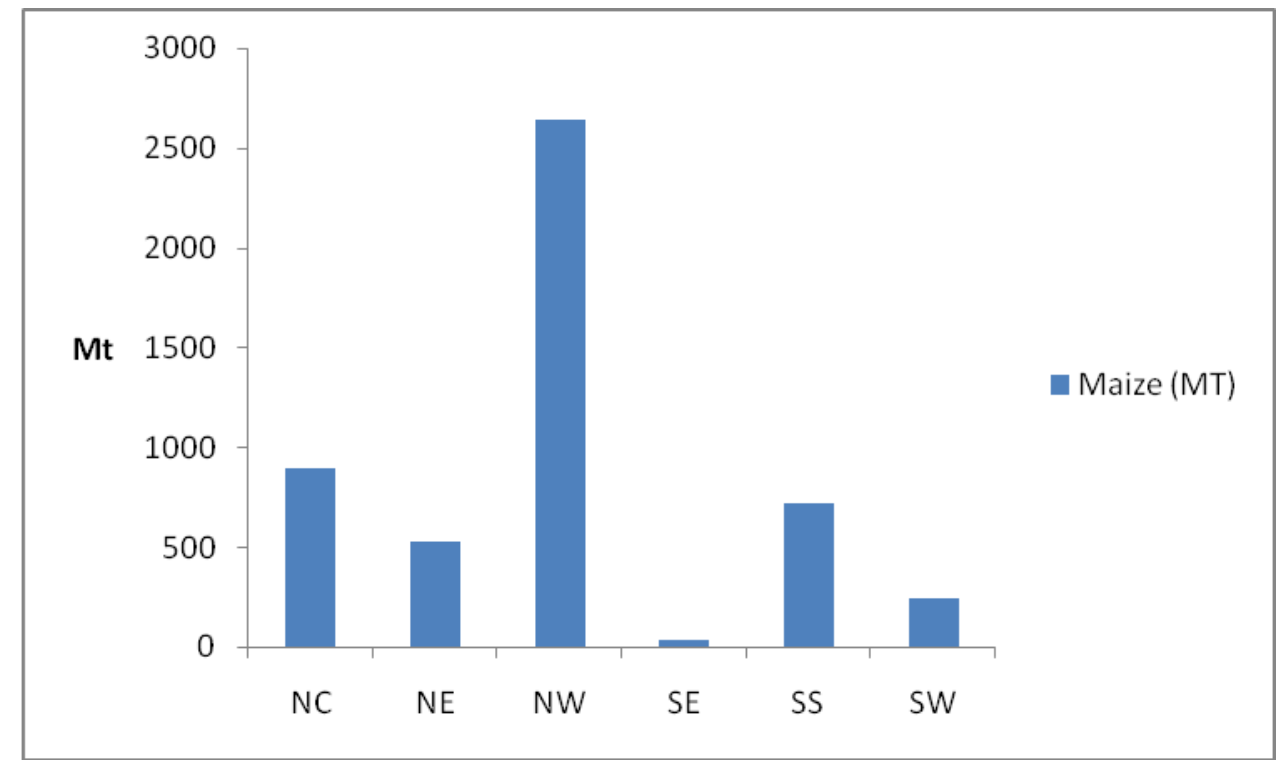

Figure 4: Quantities of maize seeds redeemed on zonal basis (Mt)

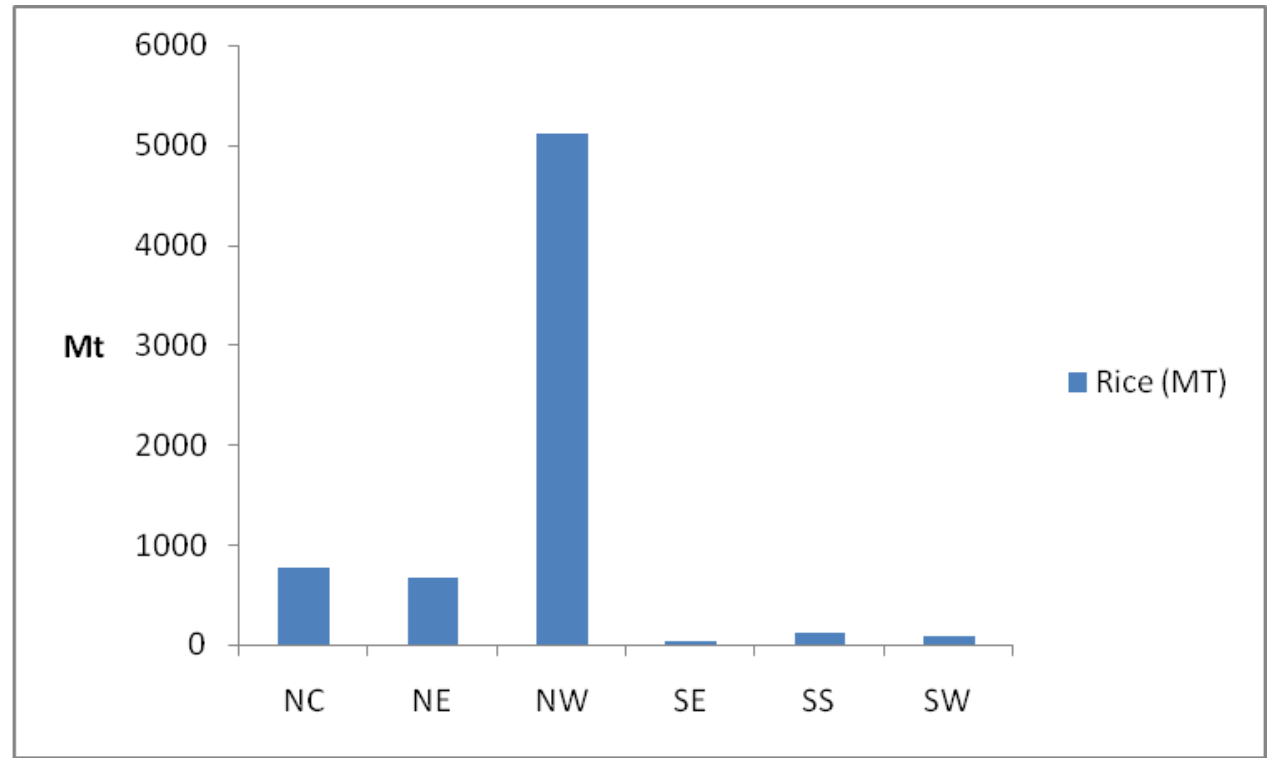

Figure 5: Quantities of rice seeds redeemed on zonal basis (Mt) 
Table 4: Result of Multiple Regression Analysis

\begin{tabular}{|c|c|c|c|c|}
\hline Variable & Linear & Semi-Log & Double-Log & Exponential \\
\hline Constant & $\begin{array}{c}5948.37 \\
(1.66)\end{array}$ & $\begin{array}{c}-3526,5 \\
(-4,43)^{* * *}\end{array}$ & $\begin{array}{c}-1,03306 \\
(-2.88)^{* * *}\end{array}$ & $\begin{array}{c}9.317688 \\
(25.56)^{* * *}\end{array}$ \\
\hline Farmers registered $(\mathrm{X} 1)$ & $\begin{array}{c}0.0029 .4 \\
(0.14)\end{array}$ & $\begin{array}{c}2079.927 \\
(0.24)\end{array}$ & $\begin{array}{c}0.03541 \\
(0.92)\end{array}$ & $\begin{array}{c}1.67 \mathrm{E}-06) \\
(0.83)\end{array}$ \\
\hline Farmers turn out (X2) & $\begin{array}{c}0.717876 \\
(31.07)^{* * *}\end{array}$ & $\begin{array}{l}30732.07 \\
(6.89)^{* * * *}\end{array}$ & $\begin{array}{c}1.047231 \\
(52.14)^{* * *}\end{array}$ & $\begin{array}{l}1.83 \mathrm{E}-05 \\
(7.79)^{* * *}\end{array}$ \\
\hline Active Input Redemption Centers (X3) & $\begin{array}{c}83.26952 \\
(0.54)\end{array}$ & $\begin{array}{c}4683.419 \\
(0.62)\end{array}$ & $\begin{array}{c}0.01769 \\
(0.52)\end{array}$ & $\begin{array}{c}-0,0016 \\
(-0,10)\end{array}$ \\
\hline Total Agro-input Redemption Center (X4) & $\begin{array}{c}-148,688 \\
(-1,34)\end{array}$ & $\begin{array}{c}-15951,8 \\
(-1,56)\end{array}$ & $\begin{array}{c}-0,05403 \\
(-1,18)\end{array}$ & $\begin{array}{c}0.026369 \\
(2.34)^{* *}\end{array}$ \\
\hline No of Active Local Govt. Areas (X5) & $\begin{array}{c}18.21815 \\
(0.14)\end{array}$ & $\begin{array}{c}13921.35 \\
(1.92)^{*}\end{array}$ & $\begin{array}{c}-0,00393 \\
(-0,12)\end{array}$ & $\begin{array}{c}-0,04543 \\
(-3,34)^{* * *}\end{array}$ \\
\hline Total Local Govt in State (X6) & $\begin{array}{c}-313,698 \\
(-1,96)^{*}\end{array}$ & $\begin{array}{c}15714,14 \\
(-1,32)\end{array}$ & $\begin{array}{c}-0,06129 \\
(-1,15)\end{array}$ & $\begin{array}{c}-0,02146 \\
(-1,32)\end{array}$ \\
\hline R Square & 0.98 & 0.77 & 0.99 & 0.92 \\
\hline Adj. R Square & 0.98 & 0.72 & 0.99 & 0.85 \\
\hline
\end{tabular}

Source: Output of Regression Analysis based on secondary data

Notes:

$* * *$ Implies statistical significance at $\mathrm{p}<0.001$ probability

** Implies statistical significance at $\mathrm{p}<0.005$ probability

* Implies statistical significance at $\mathrm{p}<0.10$ probability

- Figures in parentheses are t-values

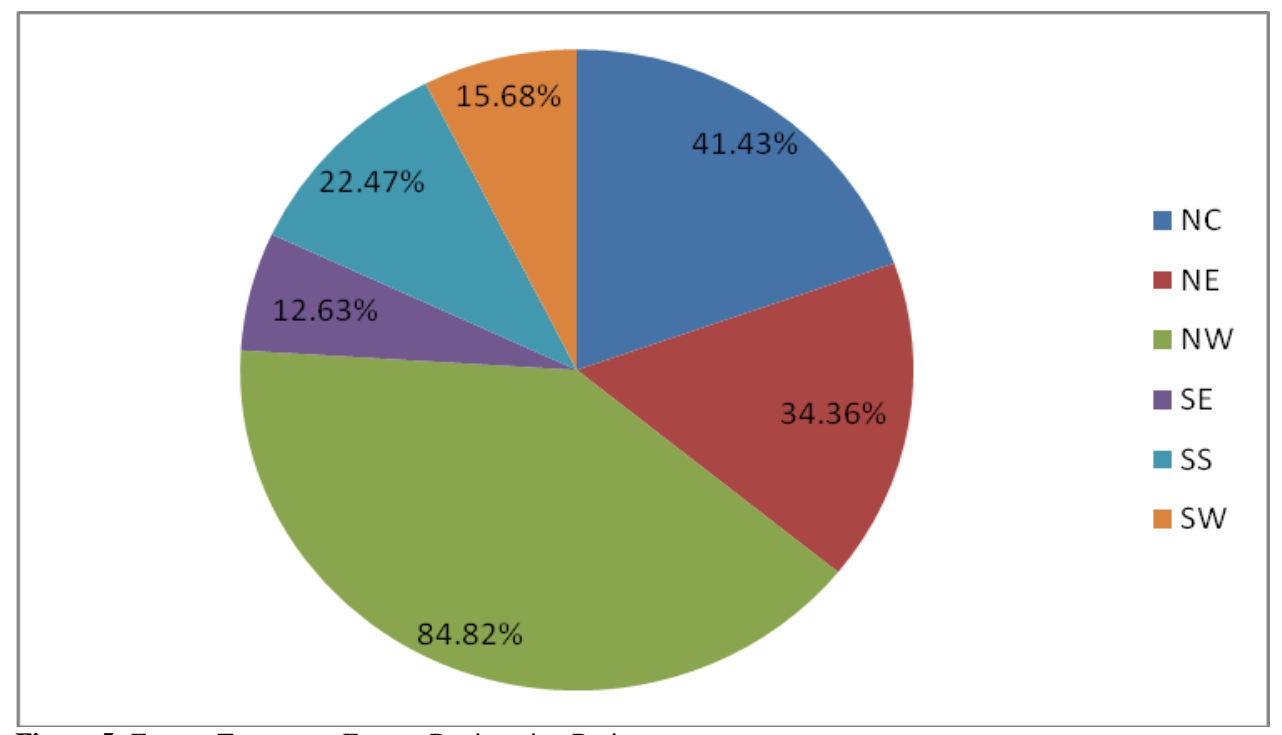

Figure 5: Farmer Turnout to Farmer Registration Ratio

\section{Determinants of Farmers Redeemed with Agricultural-inputs (Fertilizers)}

From the results presented on Table 4, the semi-log functional form was chosen as the lead equation inspite of it having the least $\mathrm{R}^{2}$ given the logical nature of the significant variables and its adherence to a priori expectations. The R squared of .77 shows that $77 \%$ of the variation in the numbers of farmers redeemed with fertilizers was accounted for by the six included independent variables put together. The adjusted $\mathrm{R}$ square also supported the claim with a value of 0.72 or $72 \%$. This implies that the independent variables explain the behaviour of the dependent variables at $72 \%$ confidence. The calculated F-statistics probability value of 0.000 also implies that there is a significant impact between the dependent variables and the independent variables. From the result, farmers turn out and numbers of active LGAs have a positive and significant effect on the number of farmers redeemed at 1 percent and 10 percent level of significance respectively. The implications of these results are that for every round of farmers' turn out for the GESS about 30,732 new farmers will be redeemed with agroinputs across the country. Every additional LGA made active under the programme could result into about 13, 921 more farmers being redeemed with agro-inputs across the country. 
Coker A. A.

\section{Challenges under the GESS and their Implications for Effective Implementation of the On-going Transformation Agenda}

Numerous issues have cropped up in the course of the implementation of the on-going GESS. Analysis of available secondary data on farmer registration and turn-out suggested that aside the North West Zone where the ratio of farmer turn-out to registration stood at $84.82 \%$ (Figure 5), the performance across the other zones which ranged from $12.6 \%-41.43 \%$ suggested that there may have been mobilization related issues in most of the other zones bordering on either capacity limitations on the part of the personnel involved, administrative problems arising from limited registration materials, ignorance or inadequate information on the part of the farmers on registration modalities or probably, hijack of the registration process by the elite or political class. Similarly, the ratio of farmer turn-out to farmer redeemed (Figure 6) which ranged from $58.66 \%$ in the North West to $72.72 \%$ in the North East, though encouraging, indicated some operational weaknesses relating to inadequacy of available agro-inputs to cater for the registered farmers, ineffective operations of the agroinput dealers and redemption centers, sharp practices on the part of farming households, where numerous household members from a single household benefit at the expense of other qualified farming households, mobile phone network related issues, distance of redemption centers to farmer's abode, shortage of supplies or budget limitations to cope with the targeted number of farmers arising from the low allocation to agriculture sector in the national budget. NANTS (2012) revealed that though a capital budget of $\$ 41,190,240,000$ is proposed for agriculture sector in 2012 , only about less than $2 \%$ may directly affect the Transformation Agenda. According to the organization, this meager percentage demonstrates a lacuna between the commitments made by the government in the budget speech and indeed the Transformation Agenda and resource allocation. According to Osinowo (2012), specific issues constraining effective implementation of the GESS included bureaucrats' resistance to change, over dependence on foreign institutions and models, low technical capability of farmers amongst others. Coker et al., (2013) also noted that the limited access to mobile phones by the rural households and limitations of telecommunication network coverage as at 2013 , delay in the supply of inputs by agro-dealers, limited supervision and monitoring of agro-input dealers and inability to effectively operationalize the electronic scheme in some states and locations may have constrained implementation of the scheme.

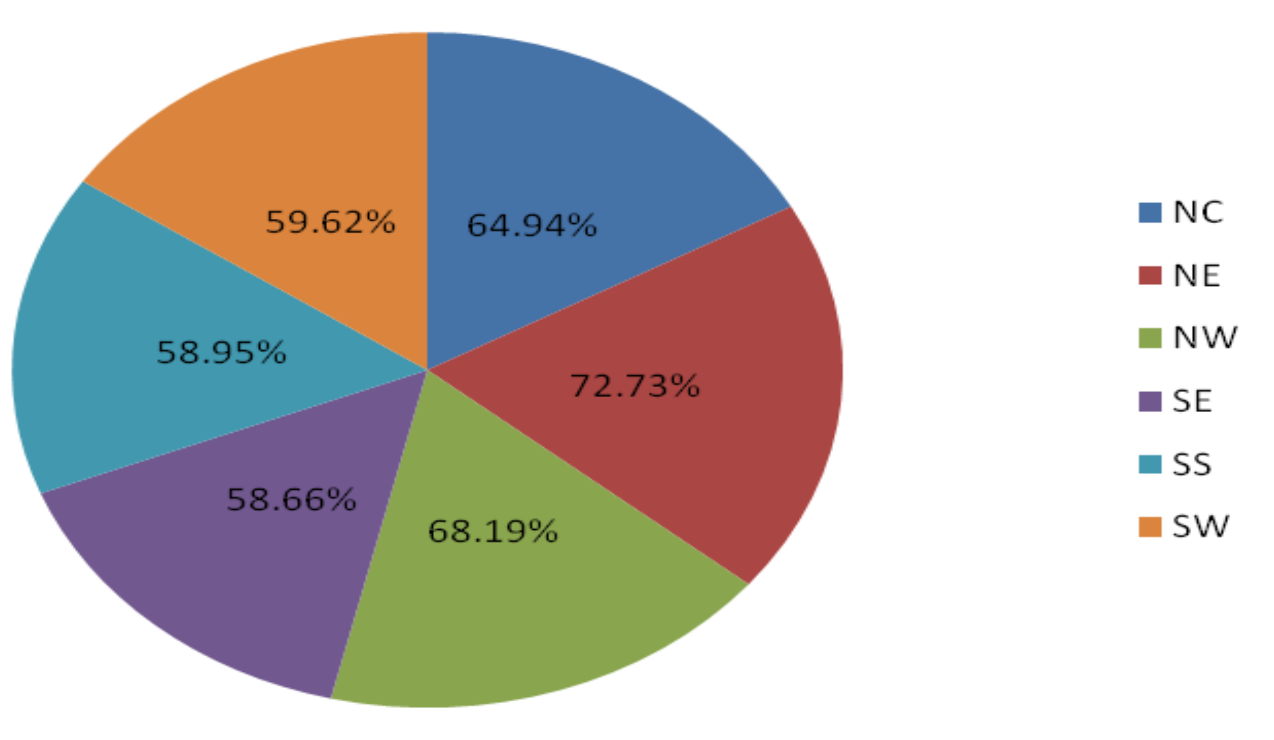

Figure 6: Farmer Turnout-Farmer Redeemed Ratio 


\section{CONCLUSIONS AND RECOMMENDATIONS}

Arising from the outcome of the analysis, the study revealed that farmer turn-out and the number of active LGAs were significant determinants of farmers redeemed with inputs across the country. Locational differences in farmers redeemed with agro-inputs were also observed to be significant across the 6 zones. Expectedly, the northern parts, comprising the North West, North East and North Central which is the food production hub of the country accounted for about $90 \%$ of the total numbers of farmers redeemed with agro-inputs across the country. Aside these, numerous issues were observed to have constrained effective implementation of the scheme bordering on weakness in farmer mobilization, administrative issues, sharp practices on the part of farming households, budget limitations, and associated technology related problems, amongst others. To enhance the effective implementation of the initiative and expand coverage, with the view to enhancing productivity and standard of living of the farmers, it is thus recommended that: (i) the State Offices of the Federal Ministry of Agriculture and the State Ministries of Agriculture /State Agricultural Development Programmes should up-scale the on-going awareness, farmer education and mobilization efforts aimed at wooing and accommodating more farmers under the scheme; (ii) effort should be made by the FMARD Regional Offices across the country to upscale supervision of field implementation, especially the activities of the agro-input redemption centers and the agro-input dealers, with a view to ensuring better service delivery; (iii) the Federal Department of Rural Development ensures that all on-going smallholder focused donor supported food security related projects and programmes such as the IFAD Assisted Community Based Natural Resource Management Programme, Value Chain Development Programme and World Bank Assisted Fadama-III Plus are effectively aligned with the scheme with a view to complementing achievement and covering farmers yet to benefit from the scheme; the Federal Government should upscale and embark on targeted budgetary allocation to specific initiatives like the GESS within the overall allocation to the agriculture sector;(iv) the FMARD should engage more service providers to complement the efforts of Cellulant, the organization overseeing the implementation of the GESS implementation; (v) there should be targeted mobile phone support rather than blanket approach, but, with focus on the resource poor farmers or core poor, particularly women and the disabled; (vi) there is need for more political will and support from the Chief Executives of the 36 States of the Federation and the Local Government Chairpersons of the 774 LGAs in making the scheme a success.

\section{REFERENCES}

Ayinde, O. E., Adewunmi, M.O. \& Omotosho, F. J. (2009). Effect of Fertilizer Policy on Crop Production in Nigeria. The Social Sciences. 4(1.) :53-58.

Ayoola, G.B. (2001). Essays on the Agricultural Economy. A Book of Readings on Agricultural Development Policy and Administration in Nigeria. T.M.A Publishers, Ibadan, Nigeria.

Banful, A. B., Nkonya, E. \& Oboh, V. (2010). Constraints to Fertilizer Use in Nigeria. Insight from Agricultural Extension Service. IFPRI discussion paper 01010.

Business Nigeria, (2013). 'E-Wallet Scheme Saved FG N29.7b in 2012 http://www.thisdaylive.com/articles/-ewallet-scheme-saved-fg-n29-7b-in2012-/144022/.

Coker, A. A. \& Adebayo, C.O. (2013) A Review of the Existing Agricultural Policy and Changes Needed to Enhance Effective Implementation of the Agricultural Transformation Agenda (ATA). Paper presented at the NAAE Conference held at Obafemi Awolowo University, Ile-Ife, Osun-State, Nigeria.

Doreo Institute (2013). Concept Note: Inclusive Growth for Small Holder Farmers, women and Youth in Staple Crop Processing zones in North Western Nigeria.

Eboh, E.C.; Ujah, O.C.; \& Amaechina, E.C. (2006). Do Government Fertilizer Subsidies Benefit Rural Poor Farmers in Nigeria? Making Sense out of Existing Data. PMMA Network Session Paper.

FMARD, (2014). Federal Ministry of Agriculture and Rural Development. Nigeria's Agriculture Transformation Agenda (ATA) Turning Nigeria into a Global Powerhouse in Agriculture.

FMARD, (2011). Federal Ministry of Agriculture and Rural Development. Presidential brief on Agricultural Transformation Agenda, Abuja, Nigeria.

Gittinger, J.P. (1988). Economic Analysis of Agricultural Projects. Second Edition. The john Hopkins University Press. Baltimore and London.

Nagy, J.G., and Edun, O. 2002. Assessment of Nigerian Government Fertilizer Policy 
and Suggested Alternative MarketFriendly Policies.

http://www.usaid.gov/downloads/reforms/assess mentoffertilizerpolicy.pdf.

National Association of Nigerian Traders (NANTS), (2012). 2012 Nigeria Agriculture Budget Appraisal. Policy Advocacy Series. Pp 1-12.

National Bureau of Statistics (NBS), (2012). Nigeria Poverty Profile 2010. Abuja, Nigeria www.nationmaster.com

Tiri, G. D., Ojoko, E. A. and Aruwayo, A. (2014). Growth Enhancement Support Scheme (GESS) and Challenges of Food Security in Nigeria: A Review. APRN Journal of Agricultural and Biological Science.. 9 .(7) : 226-232
Ojumu, S. and Adeyelu, A. (2014). Economic Analysis of Marketing Locally Milled Rice at Micro-scale in Ogoja Local Government Area of Cross River State. Nigeria Journal of Agriculture and Veterinary Sciences, .6 (1):.31-40.

Osinowo, O. A. (2012). Agricultural Transportation in a Deregulated Economy: The role of Livestock Subsector. Proceedings of the 46th Annual Conference of Agricultural Society of Nigeria, Head at Bayero University Kano. p. 4 